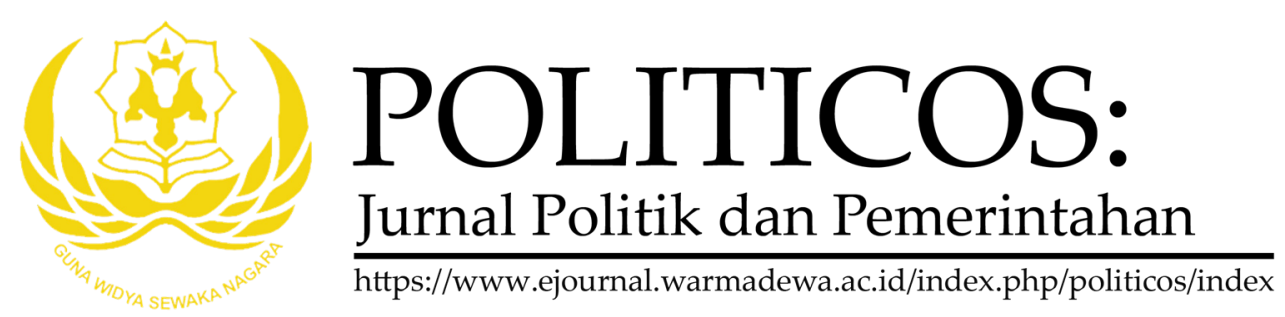

\title{
Keterlibatan Asean dalam Menangani Konflik Myanmar (Studi Kasus: Konflik Etnis Rohingya 2017 - 2019)
}

\author{
Ipung Pramudya Setiawan dan Made Selly Dwi Suryanti* \\ Universitas Cenderawasih, Jayapura \\ Corespondece Email: sellydwisuryanti@gmail.com
}

How to Cite: Setiawan, I. P \& Suryati, M. S. D. (2021). Keterlibatan Asean dalam Menangani Konflik Myanmar (Studi Kasus: Konflik Etnis Rohingya 2017 - 2019). POLITICOS: Jurnal Politik dan Pemerintahan, 1 (2): 83-97. Doi: https://doi.org/10.22225/ politicos.1.2.2021.83-97

\section{Abstract}

This paper will study about ASEAN's role on the conflict in Myanmar, specifically Rohingya ethnical conflicts in 20172019. In its development, this conflict turns out to be far from over and ASEAN as the regional organization of SouthEast Asia should take the responsibility to solve this conflict. This paper will be reviewed using descriptive qualitative approach that is based on secondary data sources. Those data sources include academic journals, books, printed and online articles, and also other relevant sources. We concluded that the involvement of ASEAN in solving the conflict in Rohingya was because the responsibility of ASEAN to protect the countries in their region. In the effort to solve the conflict of Rohingya, ASEAN never wandered off the human rights principles. Meanwhile, in the process, ASEAN was assisted by Indonesia to approach it through soft diplomacy and by the United Nations (UN) through the concept of "Responsibility to Protect". On the other hand, ASEAN also have a special team called ASEAN HUMANITARIAN ASSISTANCE (AHA). This team was specifically assigned in Rakhine and making 4 (four) recommendations according physical security, materials security, Rohingya registration, and social unification to prevent the recurrence of horizontal conflict in Myanmar.

Keywords: ASEAN; human rights; responsibility to protect; rohingya conflict

\begin{abstract}
Abstrak
Tulisan ini akan membahas tentang peran ASEAN dalam menangani konflik di Myanmar. Secara khusus, tulisan ini akan mengkaji konflik etnis Rohingya pada tahun 2017 - 2019. Melihat perkembangan yang terjadi bahwa konflik etnis Rohingya belum selesai dan ASEAN sebagai organisasi regional memiliki tanggungjawab untuk menyelesaikan permasalahan ini. Penelitian ini menggunakan pendekatan kualitatif menggunakan sumber data sekunder berupa jurnal, buku, artikel cetak dan elektronik serta sumber lainnya yang relevan. Sumber data sekunder terdiri dari jurnal akademik, buku, artikel cetak dan online serta sumber lainnya yang relevan dengan topik ini. Penelitian ini menunjukkan bahwa bahwa terlibatnya ASEAN dalam penanganan konflik Rohingya adalah karena ASEAN memiliki tanggungjawab untuk melindungi negara-negara
\end{abstract}


POLITICOS: Jurnal Politik dan Pemerintahan, 1 (2) (2021)

Keterlibatan Asean dalam Menangani Konflik Myanmar (Studi Kasus: Konflik Etnis Rohingya 2017 - 2019)

regionalnya. Dalam upaya penyelesaian konflik tersebut, ASEAN selalu berpegang teguh pada hak asasi manusia. Sementara itu, dalam prosesnya ASEAN dibantu oleh Indonesia untuk melakukan pendekatan soft diplomacy, sementara PBB dengan konsep Responsibility to Protect. Disisi lain, ASEANjuga memiliki tim khusus bernama AKA (ASEAN untuk bantuan kemanusiaan). Tim ini dikhususkan untuk bertugas di wilayah bagian Rakhine dan membuat empat rekomendasi yaitu keamanan fisik, keamanan material, registrasi Rohingya dan Penyatuan sosial untuk mencegah kembali terjadinya konflik horizontal di Myanmar.

Kata kunci: ASEAN; hak asasi manusia; responsibility to protect; konflik rohingya

\section{PENDAHULUAN}

Myanmar sebagai salah satu negara republik yang beribukota Yangon, dulunya dikenal dengan sebutan Burma. Pada 18 Juni 1989, pemerintah Junta Militer mengubah sebutan terhadap negara yang dihuni 135 etnis ini menjadi Myanmar. Heterogennya etnis Myanmar kemudian terbelah menjadi penduduk mayoritas dan minoritas. Salah satu etnis minoritas yang tinggal di Myanmar adalah etnis Rohingya. Etnis muslim ini disinyalir kurang mendapat perhatian negara, bahkan tersisihkan. Diskriminasi etnis Rohingya disebabkan lemahnya peran negara memberikan perlindungan. Diskriminasi ini kemudian diiringi tindak kekerasan secara terbuka. Dukungan kekerasan datang dari sebagian besar massa fanatik pemerintah junta militer (Keling, Saludin, Feigenblatt, Ajis, \& Shuib, 2010).

Muslim Rohingya meninggalkan Myanmar dan mengungsi ke negara lain untuk menghindari tindak kekerasan. Hingga Oktober 2018, sebagaimana dilansir laman berita BBC korban jiwa yang terbunuh karena kekerasan Myanmar mencapai jumlah ribuan. Pengungsi yang keluar dari Myanmar bertambah, nyaris 1 juta orang memilih pergi dari Myanmar sebelum menjadi target kekerasan (BBC,
2019). Hal ini bukanlah hal baru, sebab penganiayaan ini terlah terjadi sejak 1948 di mana pada saat itu Myanmar merdeka dari kekuasaan Inggris (Hossain, 2017).

Secara historis keberagaman etnis di Myanmar tidak dapat dilepaskan dari pendudukan Inggris pada 1824. Lebih satu abad Inggris menjadikan Myanmar sebagai daerah jajahan dengan menyerap hasil pertanian beras. Pemerintahan Inggris merekrut tenaga kerja migran untuk menghasilkan laba yang tinggi dari tanah kekuasaannya. Pada abad ke-17 kebijakan ini berimbas pada banyaknya etnis Rohingya yang masuk ke Myanmar dan menurut data sensus, kisaran tahun 1871 dan 1911, populasi penduduk Muslim di Myanmar dengan pesat mengalami peningkatan hingga tiga kali lipat (Hossain, 2017).

Inggris juga berjanji untuk menyebut tanah yang dipisahkan oleh Rohingya sebagai "Wilayah Negara Muslim" sebagai imbalan atas jasa mereka mendukung Inggris. Loyalitas muslim Rohingya terhadap Inggris terbukti pada pecahnya Perang Dunia II. Dukungan ini berseberangan dengan kubu nasionalis Myanmar yang berpihak pada Jepang. Usai Perang Dunia II, Inggris kemudian memberi Rohingya posisi strategis dalam struktur 
POLITICOS: Jurnal Politik dan Pemerintahan, 1 (2) (2021)

Keterlibatan Asean dalam Menangani Konflik Myanmar (Studi Kasus: Konflik Etnis Rohingya 2017 - 2019)

pemerintahan. Pemerintah Inggris berjanji akan memberi daerah otonom bagi Rohingya, tapi tidak direalisasikan secara langsung.

Setelah kemerdekaan, Rohingya menagih janji pembentukan daerah otonom, tetapi pemerintah menolak pengajuan tersebut. Bagaimanapun, bentuk dukungan Rohingya terhadap Inggris menjadi catatan buruk dalam perjuangan kemerdekaan sehingga pemerintah Myanmar dan kubu nasionalis melabeli etnis Rohingya sebagai orang asing. Pemerintah juga bersikeras menolak memberikan kewarganegaraan kepada Rohingya. Di Myanmar, banyak orang percaya bahwa Rohingya mendapat banyak keuntungan dari pemerintahan Inggris. Anggapan ini kemudian memicu bersatunya gerakan nasionalis dengan kaum Budhisme, membentuk kekuatan yang sekaligus membuat kebencian terhadap Rohingya semakin meruncing. Pada tahun 1950, beberapa orang mengajukan tuntutan terkait pengakuan Rohingya sebagai bagian dari Myanmar. Selain kewarganegaraan, mereka menuntut daerah yang dijanjikan. Namun, gerakan beberapa orang ini tidak membawa hasil yang sesuai harapan, Militer Myanmar segera menekan gerakan tersebut (Hossain, 2017).

Sepuluh tahun berselang, tepatnya pada tahun 1962, pasca terjadinya kudeta militer, sistem pemerintahan Myanmar berubah menjadi negara yang menganut demokrasi satu partai. Sistem ini menumbangkan sistem pemerintahan demokratis yang dianut sebelumnya.
Perubahan sistem pemerintahan ke demokrasi satu partai jelas tidak menguntungkan bagi Rohingya. Stigma buruk seperti orang asing dan tanpa pengakuan kewarganegaraan terhadap Rohingya melebarkan asumsi bahwa etnis ini berbahaya dan mengancam stabilitas nasional yang terbangun selama 60 tahun.

Represi terhadap Rohingya dilakukan oleh Militer Myanmar. Represi ini mencakup upaya penyiksaan, pemerkosaan, hingga pembunuhan. Pemerintah Myanmar mengeksklusi Rohingya dari sistem politik seperti pelarangan organisasi sosial politik. Tekanan lain juga meliputi aspek finansial, korporasi milik Rohingya diakuisisi pemerintah. Selain itu, kelompok Rohingya menjadi sasaran kerja paksa, ditahan tanpa pengadilan, dan diserang secara fisik. Pada tahun 1991-1992, lebih 250.000 orang berusaha meninggalakn Myanmar dengan tujuan Bangladesh.

Pada tahun 1977, ketika tentara meluncurkan program pendaftaran nasional, Rohingya dianggap sebagai warga ilegal. Pada tahun ini kekerasan terus berlanjut, sehingga 200.000an orang mengungsi ke Bangladesh. Para pejabat memanipulasi pelarian ini untuk menegaskan stigma identitas ilegal Rohingya. Pada tahun 1982, Undangundang Kewarganegaraan Myanmar secara resmi menolak pengakuan etnis Rohingya sebagai warga negara Myanmar. Muatan Undang-Undang ini memuat marka antara etnis asli Myanmar berdasarkan asal-usul atau garis keturunan sebelum Inggris menguasai Myanmar, yang artinya 
Rohingya tidak termasuk dalam pengakuan kewarganegaraan. Namun, "Human Rights Watch" membantah stigma tersebut. Apabila dilakukan penelusuran kembali pada abad ke-12, Rohingya telah menetap di Myanmar (Hossain, 2017).

Saat ini, Rohingya telah menjadi komunitas "tanpa kewarganegaraan" dengan jumlah tertinggi di dunia. Status tanpa kewarganegaraan ini merupakan otomatisasi ketiadaan jaminan hukum dan tidak terpenuhinya hak dasar. Status yang tidak diakui sebagai warga negara Myanmar menjadi titik balik bagi Rohingya sehingga kehilangan akses dalam bidang kesehatan, sektor ketenagakerjaan, dan akses ke pendidikan formal. Sehingga menjadi hal yang wajar apabila persentase buta huruf etnis Rohingya mencapai 80\% (Hossain, 2017).

Selain itu, hak beribadah mereka telah dilanggar. Karena identitas agama dan etnis mereka, negara membatasi hak mereka untuk menikah dan bergerak bebas. Tidak berhenti sampai disana, pemerintah membatasi mereka dalam status kepemilikan tanah maupun properti. Sementara hegemoni juga melekat dalam memori masyarakat Myanmar yang khawatir terhadap etnis Rohingya. Sanksi sosial seperti pembatasan jumlah anak ditujukan kepada Rohingya. Sebaliknya, mereka yang melanggar aturan ini layak dipenjara. Sehingga aturan ini secara drastis mengurangi populasi etnis Rohingya. Dukungan pemerintah terhadap aturan ini adalah labelisasi anak-anak mereka yang melanggar.
Meskipun Myanmar baru-baru ini beralih ke demokrasi, penganiayaan terus berlanjut. Dikatakan bahwa bencana kemanusiaan baru-baru ini disebabkan oleh penyerangan pos polisi oleh organisasi pemberontak baru yaitu Arakan Rohingya Salvation Army. Catatan Human Rights Watch yang mengacu pada keterangan para pengungsi di Bangladesh menyebutkan bahwa terjadi penyerangan besar-besaran militer Myanmar kepada etnis Rohingya yang diikuti pembakaran tempat tinggal mereka. Para pria dipenggal kepalanya, sementara perempuan diperkosa, dan anakanak dibunuh. Sebanyak 120.000 orang Rohingya tinggal di kamp penahanan (HRW, 2020).

Kasus yang terjadi pada etnis Rohingya ini menarik perhatian negaranegara ASEAN. Dalam kasus ini berusaha untuk mencari solusi dalam menyelesaikan konflik yang terjadi pada masyarakat Rohingya tanpa harus melakukan intervensi secara mendalam. Dalam kasus ini, sebagai salah satu negara anggota ASEAN, Indonesia melakukan upaya untuk menyelesaikan konflik tersebut dengan cara mengirimkan pesan diplomatik. Diterimanya Retno Marsudi selaku menteri luar negeri Indonesia menandai bahwa Indonesia mendapatkan kepercayaan Myanmar dalam penyelesaian konflik ini. Indonesia dan ASEAN melihat bahwa pendekatan soft diplomacy merupakan pendekatan yang paling ideal melihat Myanmar masih berada di bawah rezim militer (Bonasir, 2021).

Tulisan ini bermaksud menjelaskan 
POLITICOS: Jurnal Politik dan Pemerintahan, 1 (2) (2021)

Keterlibatan Asean dalam Menangani Konflik Myanmar (Studi Kasus: Konflik Etnis Rohingya 2017 - 2019)

bagaimana keterlibatan ASEAN sebagai organisasi regional dalam upaya penyelesaian konflik yang terjadi di Rohingya, Myanmar. Selanjutnya, dalam menjelasakan keterlibatan ini, penulis akan menggunakan beberapa konsep yaitu Konsep HAM dan Konsep Responsbility to Protect. Batasan yang penulis ambil dalam paper ini adalah pada tahun 2017 - 2019. Terakhir, sebagai acuan dan menemukan research gap, penulis menggunakan dua reviu literature untuk menjelaskan penelitian ini.

Pertama, Triono (2014) mengkaji peran asean dalam penyelesaian konflik etnis rohingya yang dalam kajiannya dikatakan bahwa ASEAN selama ini berpedoman pada prinsip non-interference. Negaranegara kawasan Asia Tenggara yang tergabung dalam organisasi ASEAN menggunakan prinsip ini dalam upaya perdamaian, sehingga dikenal dengan upaya stabilitasi dan solusi perdamaian terbaik diantara tawaran rekonsiliasi negara berkembang lain. Peran sentral menggerakkan pembangunan politik kawasan, ASEAN juga mampu membangun rasa kepemilikan satu sama lain antar negara anggotanya sehingga kebijakankebijakan ASEAN selalu dipatuhi dengan partisipasi aktif (Triono, 2014). Terkait konflik di Rohingya, sebagai negara anggota ASEAN, Indonesia turut bersuara dalam forum ASEAN. Indonesia bersuara mengenai pentingnya upaya rekonsiliasi seluruh anggota ASEAN dan mendukung penuh inisiasi diplomasi internasional. ASEAN disini baru mulai menyusun rencana dan mengajak Negara-negara anggota agar ikut berpartisipasi untuk memberikan bantuan dengan cara melakukan diplomasi terhadap Myanmar. Perbedaan dengan hasil penelitian ini adalah ASEAN telah menemukan jalan keluarnya dengan cara menerapkan konsep Responsbility to Protect (R2P). Kedua, Wakhidah (2014) dalam penelitiannya tentang "Prinsip Non-Intervensi ASEAN dalam Upaya Penyelesaian Konflik Rohingya di Myanmar" mengatakan bahwa andilnya ASEAN dalam penyelesaian konflik yang terjadi di Myanmar menunjukkan kepedulian ASEAN terhadap negara-negara anggotanya. Peran ASEAN semakin nampak ketika konflik Rohingya diusung menjadi isu transnasional. Secara fundamental, sebaran pengungsi Rohingya ke beberapa negara secara langsung menjadi gangguan stabilisasi negara-negara tempat para pengungsi berlindung. Akan tetapi, sebagaimana pendapat Nurul, isu mengenai konflik belum dipertimbangkan oleh ASEAN sebagai persoalan regional, sehingga mengalami kebuntuan untuk penyelesaian konflik. Kebuntuan pembahasan isu di tingkat regional Myanmar terhalang karena pedoman prinsip non-interferensi yang dianut ASEAN. Upaya ASEAN untuk mengajak Myanmar berdialog mengenai konflik Rohingya selalu ditolak karena alasan internal (Wakhidah, 2014). Kedua penelitian sebelumnya mengungkap upaya penyelesaian konflik Rohingya melalui forum ASEAN. Triono menekankan prinsip non-interferensi sebagai panduan penyelesaian konflik, sementara Nurul menganggap prinsip tersebut belum 
mampu menyentuh regional Myanmar dalam penyelesaian konflik. Penelitian ini bertujuan untuk melengkapi kajian sebelumnya dan fokus pada kapabilitas ASEAN dalam upaya penanganan konflik Rohingya di Myanmar dengan mengeksplorasi kemampuan dan ketidakmampuan ASEAN dalam menangani konflik Myanmar.

\section{II.METODE}

Metode yang digunakan dalam penulisan ini ialah metode deskriptif kualitatif. Metode ini digunakan untuk menggambarkan fenomena konflik Rohingya di Myanmar dengan melihat bagaimana keterlibatan ASEAN dalam menangani konflik tersebut. Dalam mengumpulkan informasi dan penyempurnaan makalah, penulis menggunakan sumber data sekunder. Data sekunder ini biasanya bisa didapatkan melalui buku, publikasi pemerintah, catatan internal organisasi, laporan, jurnal, hingga berbagai situs yang berkaitan dengan informasi yang sedang dicari (Moloeng, 2011). Data sekunder penelitian ini berasal dari beragam informasi yang tersedia. Peneliti mengumpulkan semua informasi untuk mendukung kebutuhan data dalam bentuk teks yang berasal dari berbagai sumber.

\section{III.HASIL DAN PEMBAHASAN}

Prinsip-Prinsip ASEAN

ASEAN didirikan pada tahun 1967 dalam konteks regional dan internasional.
Awalnya, ASEAN beranggotakan lima negara, yakni Indonesia, Malaysia, Thailand, Singapura dan Filipina. Perbedaan masing-masing negara dari segi bahasa, kultur, agama, etnis, pengalaman historis, maupun secara geografis bukan menjadi penghambat tumbuhnya rasa kebersamaan. ASEAN tidak dibuat dengan kemudahan. Sebelum ASEAN, dibentuk organisasi tingkat regional dengan anggota yang terbatas. Pembentukan awalnya dimulai pada tahun 1961 dengan pembentukan Association Of Southeast Asia (ASA). Namun konflik antara Filipina dan Malaysia yang telah menggagalkan upaya awal ini.

Pembentukan ASEAN tidak dapat menjamin bahwa tidak akan ada konflik regional antar negara anggotanya. Pada KTT ASEAN (KTT) pertama yang diadakan di Bali pada 24 Februari 1976, dikeluarkanlah "Deklarasi Kesesuaian ASEAN" atau "Deklarasi Bali Concord". Para petinggi ASEAN berharap ASEAN menjadi kawasan damai dan netral, bebas dari campur tangan pihak luar oleh negaranegara besar diluar kawasan ASEAN (nn, 2015). (Jones, 2009)

Sejak Sembilan tahun berdiri, ini merupakan periode yang penting karena pada periode itulah negara-negara berinteraksi. Menjadi sumber nilai bagi pembentukan norma, dan kelak menjadi kontinuitas hubungan antar negara. Amitav Acharya menjelaskan bahwa norma ASEAN berasaskan pada dua nilai. Pertama, organisasi seperti ASEAN perlu mempertimbangkan nilai dan norma 
organisasi regional berbeda dan belajar dari organisasi-organisasi tersebut. Kedua, nilai sosial, politik, maupun budaya setempat perlu dijadikan pedoman sekaligus sumber daya yang kuat (Acharya, 1994). Traktat Persahabatan dan Kerjasama (Treaty of Friendship and Cooperation) yang ditandatangani pada KTT ASEAN pertama yang diadakan di Bali pada tahun 1976 pada umumnya dianggap perwujudan nilai globalitas yang menjadi dasar organisasi regional. Pertemuan negara-negara ASEAN di Bali menghasilkan beberapa kesepakatan:

Semua negara anggota ASEAN harus saling menghormati kemerdekaan, kedaulatan, dan integritas wilayah semua bangsa,

Semua negara anggota ASEAN setiap negara berhak memelihara keberadaanya dari campur tangan, subversi,kekerasan dari kekuatan luar

Semua negara anggota ASEAN dilarang mencampuri urusan internal negara lain

Mengedepankan diplomasi dengan jalan damai dalam penyelesaian perbedaan dan pertikaian, kekerasan.

Menolak ancaman penggunaan

Acharya menjelaskan bahwa, dalam evolusi ASEAN sebagai organisasi regional, beberapa norma dasar telah berkembang. Setidaknya ada empat pedoman dan prinsip hidup di ASEAN. Yang pertama adalah menentang menggunakan kekuatan dan memprioritaskan solusi melalui jalan damai, kedua, otonomi regional, ketiga prinsip ini tidak mengganggu urusan negara lain dan keempat, menolak untuk membentuk aliansi militer dan menekankan kerja sama pertahanan bilateral (Jones, 2009).

\section{Pelanggaran HAM di Wilayah Rakhine}

Pada tahun 2017 terjadi operasi militer yang dilakukan militer Myanmar di Desa Gu Dar Pyin, Negara Bagian Rakhine. Operasi ini merilis serangkaian pembantaian dan ratusan ribu rumah Muslim Rohingya di Myanmar dibakar. Militer Myanmar menyatakan hanya 19 teroris yang tewas dalam operasi 2017 kala itu. Namun, menurut penelitian badan hak asasi manusia menunjukkan data berbeda. Pembantaian Agustus 2017 tersebut menewaskan ratusan warga sipil (Siba \& Qomari'ah, 2018).

Sementara Operasi perdamaian Masyarakat Rohingya dan Hak Asasi Manusia (Arakan) menganulir bahwa operasi tersebut menewaskan sekitar 250 orang. Pengawas hak asasi manusia mengatakan sedang melakukan pemantauan, mengumpulkan data, dan secara langsung melakukan penyelidikan keluarga korban yang menjadi korban pembantaian di Rohingya serta orang yang selamat dari kamp pengungsi Cox's Bazar di Bangladesh.

Data tersebut merupakan hasil investigasi komisi penyelidikan yang disetujui oleh militer dan pemerintah 
Myanmar. Data ini menjadi bantahan atas klaim pemerintah bahwa, total 19 orang tewas dalam penumpasan pada 27-28 Agustus 2017. Untuk memberikan kesan baik, pemerintah dan militer Myanmar melabeli orang-orang yang tewas ini sebagai "teroris." Beberapa hari kemudian, kejadian ini memicu kejadian lain yang menyebabkan ribuan korban jiwa. Rohingya memaksa hampir satu juta dari mereka meninggalkan rumah mereka dan berlindung di negara tetangga Bangladesh.

Setelah tindakan kejam itu terungkap, badan pencari fakta PBB mengatakan bahwa Myanmar telah menambah catatan buruk kemanusiaan karena telah melakukan genosida terhadap penduduknya. Human Rights Watch memaparkan hal serupa dalam laporannya pada Juli tahun 2020 yang menyebutkan bahwa telah tindak kekerasan berskala besar di Desa Rakhine. Pembantaian besarbesaran terhadap 300 sampai 400an orang Rohingya melibatkan ratusan aparat militer dan polisi dengan senjata lengkap. Pengawas hak asasi manusia global mengutip "Laporan Misi Pencari Fakta Perserikatan Bangsa-Bangsa" yang memaparkan secara tragis praktik kekerasan yang dilakukan tentara terhadap para perempuan Rohingya. Dalam laporan ini, pengawas hak asasi manusia mengatakan bahwa perempuan Rohingya diculik, kemudian diperkosa dalam kompleks militer (Siba \& Qomari'ah, 2018). Laporan ini juga mencatat kondisi tragis, dimana korban pembantaian dikuburkan secara massal pada lima titik yang telah ditentukan.
Laporan tersebut langsung direspon pemerintah dan militer Myanmar dengan bantahan. Berdasarkan versi pemerintah dan militer, operasi ini dilakukan untuk langkah keamanan dari serangan Arakan Rohingya Salvation Army dan insiden tersebut hanya menewaskan 19 orang. Di samping itu, pemerintah berkilah dari tuduhan adanya kuburan massal. Menurut versi pemerintah dan militer, mayat 19 orang yang jadi korban tewas dikuburkan dengan layak.

Pada tanggal 30 Juni, dilakukan pengadilan militer di Myanmar. Berdasarkan putusan tersebut, tiga personel militer dinyatakan bersalah atas insiden $\mathrm{Gu}$ Dar Pyin. Badan Hak Asasi Manusia Rohingya kemudian membantah pengadilan militer tersebut karena sarat dengan unsur politis dan tidak transparan. Lembaga ini juga mengusulkan agar persoalan Myanmar dibawa ke Mahkamah Pidana Internasional dan Mahkamah Internasional. Usulan ini bertujuan untuk mengurangi potensi ketidakadilan putusan dan menyelesaikan masalah akuntabilitas putusan.

Di samping itu, lembaga HAM ini mendesak agar dokumen putusan dan langkah hukum peradilan militer Myanmar dibuka secara transparan. Tim Rohingya merespon desakan ini dengan kesiapan. Mereka telah melakukan pendataan detail tentang kejadian tersebut dan bersiap untuk mengungkap detail tentang metode pengumpulan data dan bersedia untuk kerja sama dalam proses verifikasi. 
Amnesty International mencatat bahwa pengungsi yang berlari ke perbatasan Bangladesh berjumlah lebih dari 750.000. Para pengungsi Rohingya ini ratarata wanita dan anak-anak mengungsi setelah militer Myanmar menindak etnis Muslim pada Agustus 2017. Tragedi ini telah mendorong jumlah orang yang dianiaya di Bangladesh menjadi lebih dari 1,2 juta (Nadria \& Christiyaningsih, 2020).

Berdasarkan penjelasan di atas, pemerintah Myanmar jelas menyembunyikan "pembersihan etnis" dari dunia. Namun, pada akhirnya terungkap bahwa pemerintah Myanmar terbukti melakukan pelanggaran HAM yang sangat berat. Bahkan masyarakat Rohingya selama ini tidak mendapatkan hak kewarganegaraan di Myanmar. Jelas tindakan ini sangat merugikan bagi Negaranegara tetangga, misalnya para pengungsi yang terus berdatangan karena mereka tidak punya tempat untuk pulang. Penjelasan tersebut berkaitan dengan konsep HAM yang penulis gunakan.

\section{Hak Asasi Manusia atau HAM} merupakan hak yang melekat pada manusia sejak lahir dan menjadi bagian dari entitas sosial masyarkat. Sebutan asasi merujuk pada tidak adanya pembedaan pada bangsa, ras, agama, golongan, dan jenis kelamin. Sehingga HAM diartikan sebagai hak yang bersifat universal. Substansi hak asasi bermuara pada asumsi bahwa semua orang mendapat kesempatan untuk berkembang sesuai bakat dan cita-cita yang diinginkannya (Budiharjo, 1985).
Dari kasus tersebut dapat dilihat bahwa pelanggaran HAM yang terjadi lebih tertuju pada pelanggaran hak sipil. Arti kata sipil bersandar pada peran pemerintah maupun lembaga negara lainnya untuk memberikan perlindungan terhadap hak bebas kepada individu. Perlindungan ini mencakup perlindungan individu dari tindakan pelanggaran yang tanpa alasan, dan perlindungan hak politik dari bentuk diskriminasi dalam kehidupan bernegara. Faricha (2013) menjelaskan bahwa hak-hak sipil melingkupi jaminan integritas fisik masyarakat dan keselamatannya, negara melindungi sipil dari segala bentuk diskriminasi seperti penyandang disabilitas baik fisik maupun mental. Perlindungan dari diskriminasi termasuk pula diskriminasi berbasis gender, agama, ras, asal-usul kebangsaan, umur, serta orientasi seksual. Hak sipil pada segi lain mengungkapkan bahwa setiap individu berhak mendapat kebebasan dalam berpikir, berbicara, dan kebebasan pers (Faricha, 2013).

Hak-hak sipil dianggap sebagai hak alamiah yang melekat secara organik pada diri seseorang. Thomas Jefferson menjelaskan bahwa orang memiliki kebebasan untuk menganulir haknya bersandar dari hukum alamiah dan bukan pemberian hakim agung. Berdasarkan penjelasan di atas, dapat dilihat bahwa pembatasan akses kepada masyarakat Rohingya, ketidakadilan yang dirasakan masyarakat Rohingya akibat tidak mendapatkan hak warga negaranya adalah bentuk pelanggaran HAM pada poin perlindungan hukum yang sama tanpa 
diskriminasi. Juga berkaitan dengan pelanggaran hak yaitu hak untuk hidup, hak bebas dari siksaan, perlakuan atau penghukuman yang kejam, tidak manusiawi, atau merendahkan martabat, dan berkaitan dengan pelanggaran ha katas perlindungan hukum yang sama tanpa diskriminasi.

\section{Keterlibatan ASEAN dalam Mengupayakan Penyelesaian Konflik}

Sebagai organisasi regional di Asia Tenggara, komitmen ASEAN merupakan komitmen untuk mengakhiri konflik yang menyebabkan terjadinya krisis kemanusiaan yang menimpa etnis Rohingya di Myanmar. Namun pernyataan tersebut belum dapat dibuktikan karena norma dan prinsip non-interferensi yang dianut oleh ASEAN menjadi dasar bagi kelangsungan hubungan antar anggota ASEAN, sekaligus menjadi penghambat pembubaran mekanisme di dalam ASEAN. Indonesia sebagai salah satu negara anggota ASEAN yang mayoritas penduduknya beragama Islam juga turut prihatin dengan kondisi masyarakat Rohingya di Myanmar. Keprihatinan Indonesia dapat dilihat dari peran aktif Indonesia dalam memantau dan merespon konflik Myanmar. Akan tetapi, melampaui hal itu, dunia internasional mengapresiasi pemerintah Indonesia karena keberhasilannya berdialog dengan pemerintah Myanmar. Dengan keberhasilan ini Indonesia jadi negara pertama yang diterima otoritas Myanmar terkait krisis kemanusiaan etnis Rohingya.

Pelanggaran HAM terbesar yang terjadi di Asia Tenggara pada tahun 2017 terkait krisis Rohingya telah membawa kita pada peran ASEAN dalam menyelesaikan isu-isu ASEAN. Pertanyaannya adalah upaya apa yang telah dilakukan ASEAN. Selain itu, dapatkah ASEAN berperan dalam menyelesaikan kasus-kasus kemanusiaan di kawasannya. Kecuali Thailand, semua negara anggota Asia Tenggara adalah bekas jajahan negaranegara Barat. Hanya dengan cara inilah negara-negara Asia Tenggara dapat benarbenar menjaga kedaulatannya. Merujuk pada pengalaman masa lalu, mereka tidak ingin lagi terjadi penjajahan di Asia Tenggara. Karena itu, mereka menutup pintu bagi negara mana pun (termasuk negara Asia Tenggara) untuk ikut campur dalam urusan internal negara lain. Lantas, bagaimana jika masalahnya merupakan masalah serius yang menyebabkan negara lain terancam? Kasus Rohingya menjadi salah satu rujukan ketika negara tidak selalu mampu menanggung bebannya sendiri. Selain itu, masalah tersebut mengganggu keamanan negara lain. Misalnya pengungsi Rohingya yang mencari suaka di negara lain merupakan masalah bersama di negara-negara Asia Tenggara, dan menjadi tanggung jawab organisasi regional di kawasan yaitu ASEAN.

Myanmar tidak terbuka untuk negaranegara Asia Tenggara tentang masalah hak asasi manusia. Tidak ada yang bisa menyalahkan Myanmar dari negara-negara Asia Tenggara yang memutuskan untuk menutup diri. Pada 2017, Myanmar memulai dialog dengan negara Indonesia. 
Faktanya, Myanmar tertutup bagi partai politik asing karena krisis Rohingya. Karenanya, hal ini membuat negara lain sulit merangkul Myanmar untuk menyelesaikan kasus Rohingya. Pada sisi lain, upaya penyelesaian masalah yang terjadi di Myanmar dipersulit oleh prinsip non-intervensi, sehingga negara anggota ASEAN tidak bisa masuk mencampuri urusan internal atau regional negara.

Berdasarkan prinsip tersebut integrasi negara-negara ASEAN semakin melemah sehingga menghambat proses konsolidasi negara-negara yang ada di Asia Tenggara. Selain itu, karena prinsip ini peran dan upaya ASEAN dalam penyelesaian konflik kemanusiaan Myanmar terhambat. Penyebutan prinsip non-intervensi dan perbedaan pendapat di antara negaranegara ASEAN tentang norma hak asasi manusia telah menempatkan ASEAN pada posisi yang sulit dan mempersulit negara anggota untuk mencapai kesepakatan tentang masalah hak asasi manusia di Myanmar. Selain itu, semua negara anggota ASEAN memiliki sensitifitas tersendiri terkait urusan kedaulatan negara.

Indonesia dalam pertemuan bilateral yang mengutus Menteri Luar Negeri Retno LP Marsudi berdialog dengan Daw Aung San Suu Kyi selaku de facto pemimpin Myanmar. Dalam dialog ini dibahas desakan terhadap pemerintah Myanmar untuk menghentikan konflik dan kekerasan Rohingya. Pada sisi lain, pemerintah Myanmar didesak untuk memberi akses bantuan kemanusiaan bagi Indonesia dan ASEAN di Rakhine (NN, 2019). Upaya
ASEAN dan pertemuan bilateral antara Indonesia dan Myanmar diyakini belum mampu menghentikan krisis kemanusiaan di Myanmar karena pemerintah Myanmar belum berupaya untuk melindungi Rohingya.

Serangan sistematis dan terorganisir oleh pemerintah Myanmar terhadap orangorang Rohingya dapat diklasifikasikan sebagai kejahatan terhadap kemanusiaan dengan risiko genosida yang tinggi. Jika kekerasan pemerintah tidak segera dihentikan, berdasarkan konsep hukum internasional, maka komunitas internasional akan bertindak melawan Myanmar. Istilah ini dikenal dengan sebutan Responsibilitas Melindungi atau R2P. Sehubungan dengan konflik Rohingya, Pemerintah Myanmar terbukti mengabaikan tanggung jawab perlindungan warga sipil, sehingga konsep R2P dapat diterapkan untuk menyelesaikan konflik tersebut. Dalam konteks R2P, setelah Indonesia maupun organisasi internasional seperti Organisasi Konferensi Islam (OKI) mencoba upaya dialog dengan Myanmar tanpa membuahkan hasil ke arah penyelesaian konflik. Maka kasus kemanusiaan di Rakhine sudah seharusnya menjadi tanggung jawab Perserikatan Bangsa-Bangsa untuk menerapkan konsep R2P.

Prinsip Responsbility to Protect lahir karena maraknya pelanggaran berat HAM pada realitas internasional. Gagalnya humanitarian intervention dalam upaya penyelesaian beragam konflik kemanusiaan di tingkat internasional serta tidak 
POLITICOS: Jurnal Politik dan Pemerintahan, 1 (2) (2021)

Keterlibatan Asean dalam Menangani Konflik Myanmar (Studi Kasus: Konflik Etnis Rohingya 2017 - 2019)

kegagalannya meraih dukungan internasional menjadi dasar lahirnya konsep ini (Djundjunan \& Wirakara, 2009). Kegagalan humanitarian intervention disinyalir karena maraknya nuansa politis atau politik kepentingan dari negara tertentu. kurangnya legalitas yang jelas melalui humanitarian intervention seringkali diikuti dengan konflik kepentingan dan tanpa mandat. Humanitarian intervention dianggap sebagai upaya yang ilegal karena sering melukiskan dominasi negara superpower terhadap negara lemah (Frank, 2003).

Pada tanggal 6 November 2017, Pernyataan Dewan Keamanan melalui Precidential Statement S/PRST/2017/22 memuat respon Dewan Keamanan terhadap konflik di Myanmar. Pernyataan ini sebagai bukti diterapkannya konsep Responsibility to Protect karena kegagalan Myanmar menjalankan tanggung jawabnya melindungi Rohingya. Jaminan perlindungan hak asasi manusia bagi warga sipil telah gagal diberikan pemerintah Myanmar. Pada langkah selanjutnya, Perserikatan Bangsa-Bangsa melalui Dewan Hak Asasi Manusia membentuk tim pelapor yang khusus memantau situasi hak asasi manusia di Myanmar serta misi pencari fakta untuk mengatasi krisis kemanusiaan sebagai tindakan pencegahan langsung terkait dengan konsep tanggung jawab untuk melindungi, dengan memeriksa dan mencari bukti. terkait tindak kekerasan yang dilakukan oleh otoritas Myanmar terhadap Rohingya (Tun, 2016).

Sementara langkah yang diterapkan
ASEAN pada sisi lain adalah menyelesaikan krisis kemanusiaan melalui pembentukan badan ad hoc dan menggerakkan lembaga sebelumnya yang fokus pada kemanusiaan. Pada tahun 2011 ASEAN membentuk badan mitigasi bencana yang disebut dengan AHA Centre (ASEAN Coordinating Centre for Humanitarian Assistance on disaster management) sebagai respon terhadap bencana yang terjadi di negara yang menjadi kawasan Asia Tenggara (BBC Indonesia, 2017). Lembaga ini fokus pada upaya tanggap bencana yang terjadi di negara kawasan Asia Tenggara, baik bencana alam maupun non-alam. Berkaitan dengan krisis kemanusiaan di Myanmar, para pemimpin ASEAN menyetujui pembentukan satuan tugas ad hoc yang bertujuan untuk memfasilitasi proses pemulangan para pengungsi Rohingya kembali ke Myanmar. Satuan tugas tersebut beranggotakan para ahli yang telah ditunjuk Sekretaris Jenderal ASEAN. Satuan tugas ini berkonsultasi dan bekerjasama dengan negara anggota ASEAN.

Terbentuknya satgas ad hoc ini mendapat sambutan baik pemerintah Myanmar. Sambutan hangat ini didasari fokus ASEAN yang menyebut persoalan tersebut dengan isu negara bagian Rakhine. Selama ini pemerintah Myanmar menolak sebutan isu Rohingya maupun etnis muslim yang dianggap mendiskreditkan otoritas Myanmar (Pramudyani, 2019).

Kesepakatan dicapai pada rapat pleno KTT ASEAN ke-35 yang diadakan di Nonthaburi, Thailand. Pertemuan tersebut dihadiri oleh kepala negara pemerintahan 
dari 10 negara anggota termasuk Presiden Joko Widodo dari Republik Indonesia. Di bawah kepemimpinan Sekretariat ASEAN, satgas tersebut akan mengawasi pelaksanaan rekomendasi preliminary need assesment (PNA) berdasarkan laporan dari tim ASEAN Humanitarian Assistance Coordination Center (AHA Center) dan ASEAN Emergency Response and Assessment Team (ERAT).

Pada Maret 2019, tim dari ASEANERAT dan AHA Centre melakukan kunjungan ke negara bagian Rakhine guna mengevaluasi kesiapan Myanmar menerima kembalinya pengungsi Rohingya. Berdasarkan evaluasi tersebut, tim ini memberikan sebanyak empat rekomendasi bagi pemerintah Myanmar, yaitu jaminan keselamatan pribadi, keamanan materi, pendaftaran Rohingya, dan kohesi sosial untuk mencegah konflik horizontal di Myanmar. Namun, sebagaimana dampak konflik dan kekerasan pada umumnya, sebagian besar pengungsi menolak untuk kembali dengan sukarela karena ketidakpastian faktor keamanan jangka panjang.

Berdasarkan penjelasan di atas, Myanmar pada awalnya sangat tertutup atas konflik ini, namun setelah percobaan soft diplomacy yang terus dilakukan oleh Indonesia, Myanmar mulai membuka diri untuk bekerja sama agar masalah konflik ini dapat diselesaikan dengan baik. ASEAN yang awalnya tidak bisa ikut campur karena bertabrakan langsung dengan prinsip non intervensi yang mereka buat sendiri, akhirnya ASEAN bisa bertindak dengan menerapkan konsep Responsbility to Protect (R2P). Mengingat konflik yang terjadi adalah kasus pelanggaran HAM yang sangat berat membuat ASEAN tidak menyerah agar terus berusaha untuk menyelesaikan konflik antara Muslim Rohingya dan Buddha Rakhine. Sementara itu kehadiran AHA juga sangat membantu selama konflik tersebut terjadi. AHA merupakan sebuah organisasi yang bergerak di bidang kemanusiaan dan menjunjung tinggi HAM, karenanya ia hadir untuk membantu para korban yang terjadi di wilayah Rakhine.

Berdasarkan hasil dan pembahasan tersebut, dapat ditarik kesimpulan bahwa pada dasarkan ASEAN terlibat dalam upaya penyelesaian konflik di Myanmar. Khsusunya yang terjadi pada masyarakat Rohingya. Upaya tersebut dilakukan atas dasar Myanmar merupakan bagian dari ASEAN. Sementara itu dalam menjalankan aksinya ASEAN mengajak tim AHA dalam rangka memperhatikan kebutuhankebutuhan yang dibutuhkan oleh masyarakat Rohingya selama mengalami konflik. Pendekatan yang dilakukan oleh ASEAN adalah dengan soft diplomacy di mana dalam upaya melakukan negosiasi, negara Indonesia merupakan negara yang mewakili ASEAN melalui Kementerian Luar Negeri Republik Indonesia. Secara umum, kasus yang terjadi di Rohingya adalah kasus pelanggaran HAM berat, sehingga peran dari ASEAN sangat dibutuhkan. Keterlibatan ASEAN akhirnya diperbolehkan dengan menganut sistem Responsibility to Protect yang mana konsep ini merupakan bagian dari tindakan 
POLITICOS: Jurnal Politik dan Pemerintahan, 1 (2) (2021)

Keterlibatan Asean dalam Menangani Konflik Myanmar (Studi Kasus: Konflik Etnis Rohingya 2017 - 2019)

perlindungan dengan upaya perdamaian dan menjunjung tinggi hak-hak asasi manusia. Keterlibatan ASEAN secara umum memang belum terlihat maksimal sebab eskalasi konflik masih terus terjadi. Namun, dapat dilihat bahwa dengan keberadaan ASEA, konflik di Rohingya dapat ditekan dengan cara menekan pemerintah Myanmar untuk menghentikan konflik antara Rohingya dan Rakhine.

\section{DAFTAR PUSTAKA}

Acharya, A. (1994). ASEAN-UN Co-operation in Peace and Preventive Diplomacy: Its Contribution to Regional Security. The Indonesian Quarterly, Vol.22 No.3,, 222.

BBC Indonesia. (2017, Desember 5). Sejauh Apa Peran Badan Mitigasi Bencana ASEAN, AHA Centre? Retrieved from https://www.bbc.com/ indonesia/indonesia-42237888

BBC. (2019, December 11). 'Genosida' Muslim Rohingya di Myanmar: Aung San Suu Kyi menyanggah tuduhan di Mahkamah Internasional. Retrieved from BBC Indonesia: https:// www.bbc.com/indonesia/dunia-50743653

Bonasir, R. (2021). Kudeta Myanmar: Mengapa Indonesia Diharapkan Membantu Mengatasi Krisis Politik "Sahabat Lama". Jakarta: BBC News Indonesia.

Budiharjo, M. (1985). Dasar-Dasar Ilmu Politik. Jakarta: Gramedia.

Djundjunan, B. A., \& Wirakara, R. (2009). The Responsibility to Protect dalam Perspektif Hukum. Majalah Opinio Juris, Vol. I, Oktober, 46.

Faricha, A. (2013, April 4). https:// lbhyogyakarta.org/. Retrieved from Hak Sipil sebagai Pelindung Kebebasan Fundamental Individu: https:// lbhyogyakarta.org/2013/04/04/hak-sipilsebagai-pelindung-kebebasan-fundamental- individu/

Frank, T. M. (2003). Interpretation and Change in the Law of Humanitarian Intervention. In J. L. Holzgrefe, \& R. O. Keohane, Humanitarian Intervention: Ethical, Legal and Political Dilemas (pp. 204 - 231). United States: Cambridge University Press.

Hossain, M. P. (2017, September 25). The Conversation. Retrieved from Sejarah Preseuksi Rohingya di Myanmar: https:// theconversation.com/sejarah-persekusirohingya-di-myanmar- 84520

HRW, H. R. (2020). An Open Prison Without End. Burma: Human Rights Watch.

Jones, L. (2009). ASEAN and The Norm of NonInterference in Southeast Asia: A Quest for Soscial Order. -: Nuffield College Politics Group Working Paper.

Keling, M. F., Saludin, M. N., Feigenblatt, O. F., Ajis, M. N., \& Shuib, M. S. (2010). A Historical Approach to Myanmar's Democratic Process. Journal of Asia Pacific Studies, Vol 1, No 2, 132 148.

Moloeng, L. J. (2011). Metodologi Penelitian Kualitatif. Bandung: Remaja Rodaskarya.

Nadria, F., \& Christiyaningsih. (2020, Agustus 12). https://www.republika.co.id/. Retrieved from Badan HAM: Banyak Pembantaian Rohingya 2017 tak Dilaporkan: https://www.republika.co.id/ berita/qeyepf459/badan-ham-banyakpembantaian-rohingya-2017-tak-dilaporkan

nn. (2015, Maret 17). https://kemlu.go.id/. Retrieved from Sejarah dan Latar Pembentukan ASEAN: https://kemlu.go.id/portal/id/read/980/ halaman_list_lainnya/sejarah-dan-latarpembentukan-asean

NN. (2019, September 25). Kemlu.go.id. Retrieved from Menlu Retno Serukan Hentikan Krisis Kemanusiaan di Rakhine State: https:// kemlu.go.id/portal/id/read/622/view/menluretno-serukan-hentikan-krisis-kemanusiaan-di -rakhine-state 
POLITICOS: Jurnal Politik dan Pemerintahan, 1 (2) (2021)

Keterlibatan Asean dalam Menangani Konflik Myanmar (Studi Kasus: Konflik Etnis Rohingya 2017 - 2019)

Pramudyani, Y. D. (2019, November 15). Langkah

Baru ASEAN Untuk Membantu Repatriasi

Pengungsi Rohingya. Retrieved from

www.antaranews.com: https://

www.antaranews.com/berita/1165028/langkah

-baru-asean-untuk-membantu-repatriasi-

pengungsi-rohingya

Siba, M. M., \& Qomari'ah, A. N. (2018). Pelanggaran Hak Asasi Manusia Dalam Konflik Rohingya. Islamic Wolrd and Politics, Vol. 2. No. 2, 369 385.

Triono. (2014). Peran ASEAN Dalam Penyelesaian Konflik Etnis Rohingya. Jurnal TAPIs. Vol. 10 No. 2.

Tun, S. Z. (2016). A Family Stands Beside the Remains of a burned Down Market in a Rohingya Village Outside Maungdaw, Rakhine State. New York: Human Rights Watch.

Wakhidah, N. (2014). Prinsip Non-Intervensi ASEAN dalam Upaya Penyelesaian Konflik Rohingya di Myanmar. Yogyakarta: Departemen Ilmu Hubungan Internasional Fakultas Ilmu Sosial dan Ilmu Politik Universitas Gadjah Mada. 